\title{
Using soil and canopy temperature to support efficient management of irrigated vineyards
}

\author{
by J. M. Costa*, R. Egipto**, C.M. Lopes*, J. Silvestre**
}

* LEAF, DCEB, Instituto Superior de Agronomia, Universidade de Lisboa, Tapada da Ajuda Lisboa, Portugal (miguelcosta@isa.ulisboa.pt; carlosmlopes@isa.ulisboa.pt)

**INIAV, I.P., Pólo de Dois Portos,/Estação Vitivinícola Nacional, Quinta da Almoínha, 2565-191 Dois Portos,

Portugal (ricardo.egipto@iniav.pt; jose.silvestre@iniav.pt)

\begin{abstract}
Extreme heat and drought events are becoming more frequent and erratic in Mediterranean Europe. Better comprehension of spatial and temporal dynamics of heat fluxes and thermal microclimate in vineyards can support vineyard's management and minimize the impact of climate variability. Field experiments were carried out in South Portugal with two red cvs. Touriga Nacional and Aragonez (syn. Tempranillo) under deficit irrigation. Canopy temperature (Tc) is a robust predictor of plant water status, especially when measured under more stressful conditions. In parallel, soil temperature $\left(T_{S}\right)$ had a positive influence on $T_{C}$ especially at the cluster zone.
\end{abstract}

\section{Introduction (Arial, 9pt, bold)}

Climate change scenarios for South Mediterranean Europe predict longer and more severe soil water deficits and higher air and soil temperatures [1,2,3], in parallel with more frequent heat waves [4](Fraga et al., 2020). In addition, row crops with low trunk height such as grapevine are particularly prone to heat stress due to the amplified effect of soil on soil-atmosphere heat fluxes with an impact on canopy's temperature $\left(\mathrm{T}_{\mathrm{C}}\right)$ and leaf and berry physiology [5]

Soil has a major role in heat fluxes and in heat storage acting as a reservoir of energy during the day and source of heat to the surface during the night, affecting the amount of energy available for latent and sensible heat transfer [6]. In parallel with $T_{\text {air, }}$, soil temperature $\left(T_{S}\right)$ is also increasing due to climate change [7] and because of that the role and impact of Ts should be better understood; Ts influences processes such as microbial respiration, organic matter decomposition rates, hormones and nutrient availability, and may influence bud break, shoot growth and yield in grapevine [8] as well as berry composition [9]. The role soil and related temperature become even more relevant under extreme climate conditions (e.g. heat wave) which strike more frequently South European countries [3,9]. Irrigation emerged as potential solution/adaptation measure to drought and heat stresses and it has expanded in dry and warm wine regions such as in Spain, Portugal, but also France and Italy [9]. A more precise irrigation management and adequate soil and crop management are on demand by the industry. In parallel, the

use of DSS systems for more efficient vineyard management can improve viticulture sustainability and help to minimize risks due to climate conditions. DSS systems can be based in multiple parameters, using $T_{C}$ and $T_{S}$ as potential indicators of crop and soil status helping to predict and minimize risks.

In this paper we monitored the seasonal variation of weather and soil and canopy temperatures in two grapevine red varieties Aragonez (syn. Tempranillo) and Touriga Nacional subjected to deficit irrigation.

\section{Material and methods (Arial, 9pt, bold)}

Trials were located in a commercial vineyard in Alentejo, South Portugal (38 $28^{\circ} 55.0^{\prime \prime} \mathrm{N}, 7^{\circ} 32^{\prime} 46.00^{\prime \prime} \mathrm{W}$, elevation $200 \mathrm{~m}$ ), under typical Mediterranean climate conditions, with mild winter temperatures and dry and warm summers, and with air temperatures extremes (above $40{ }^{\circ} \mathrm{C}$ ) occurring in July and August, punctually. Eleven years-old vines of the varieties Touriga Nacional (TOU) and Aragonez (ARA), grafted onto 1103 P, were studied. Planting density was 2,200 vines/ha and vines were trained on Vertical Shoot Positioning system. Soil texture was a sandy-loam to siltyclay-loam, with a pH of 7,0 to 7,6, a low content in organic matter. Deficit irrigation was applied by using drip irrigation (single pipe line, 1.8 emitters/per vine, flow rate of $2.1 \mathrm{~L} / \mathrm{h}$ ).

Two Sustained Deficit Irrigation treatments were tested: 1) SDI - control, according to farm's scheduling and $30 \%$ ETc), with water applied 1 to 2 times a week from berry touch (berries beginning to touch - stage 77 of the BBCHscale for grapes) and 2) RDI (50\% of the SDI1 in 2013 and 65\% in 2014 and 2015) (Table 1). Diurnal curves of leaf water potential $\left(\psi_{\text {leaf }}\right.$ ), canopy temperature (Tc) and leaf gas exchange (net photosynthesis, stomatal conductance) were measured along three consecutive years $(2013,2014$ and 2015$)$ for both varieties.

Measurements were done at flowering/berry touch, veraison and at full maturation. Leaf water potential was measured with a Scholander pressure chamber. Leaf/canopy and soil surface temperature (Tc) were measured with 
thermography (Flir B20, 7-13 $\mu \mathrm{m}, 320 \times 240$ pixels; $\varepsilon=0.96$ ). Leaf temperature was also monitored by using thermometry with low cost two-junction, fine wires copper-constantan thermocouples.

Thermal images were complemented by RGB images. Thermal images were analysed with the ThermaCAM image analysis software (Flir, USA) and thermal patterns were analysed in Excel. Individual leaf gas exchange was measured with a Licor 6400 (Licor Inc, USA), equipped with a $2 \times 3 \mathrm{~cm}$ transparent leaf chamber. The experimental design consisted of a randomized complete block with two irrigation treatments and four replications per treatment. Relationships between Tc and water potential and stomatal conductance (gs) were assessed by Pearson correlation analysis between the variables Tc, gs and air Air vapor pressure deficit (VPD air), for the two genotypes. Statistics were done by using Pearson correlations between variables (Tc, gs, VPD air), with the Statistix 9.0, analytical software.

\section{Results and discussion}

The triennia showed marked climate variation in terms of climate conditions ( $T_{\text {air }}$, precipitation and $E$ To) (Tables 1 and 2). The years 2013 and 2015 were the warmest ones of the period and 2015 was the driest. As consequence, 2015 had the longest irrigation period and the highest use of irrigation water. (Tab.1). The year 2014 had also lower VPD ${ }_{\text {air }}$ and $T_{\text {air }}$ which resulted in the lowest value of cumulative ETo for the triennia (Tab.1).

Table1. Climate conditions and irrigation water volumes applied under SDI conditions (about 30\% of ETC), at Alentejo's wine region during 2013-2015. Average rainfall ( $\mathrm{mm}$ ); reference evapotranspiration (ETo); Irrigation volume vol. applied during irrigation period; SDI managed on the basis of leaf water potential at pre-dawn.

\begin{tabular}{|c|c|c|c|c|c|c|}
\hline YEAR & $\begin{array}{c}\text { Mean } \mathrm{T}_{\text {air }} \\
\text { (Jun - Aug) } \\
\left({ }^{\circ} \mathrm{C}\right)\end{array}$ & $\begin{array}{c}\text { Max } \mathrm{T}_{\text {air }} \\
\text { (Jun - Aug) } \\
\left({ }^{\circ} \mathrm{C}\right)\end{array}$ & $\begin{array}{c}\text { Rainfall during } \\
\text { (dormancy period) } \\
\text { (Oct - Feb) } \\
\text { (mm) }\end{array}$ & $\begin{array}{c}\text { Rainfall } \\
\text { (growth period) } \\
\text { (Mar - Aug) } \\
\text { (mm) }\end{array}$ & $\begin{array}{l}\text { Cumulative ETO } \\
\text { (Mar - Aug) } \\
\text { (mm) }\end{array}$ & $\begin{array}{c}\text { SDI } \\
\text { irrigation volume } \\
\text { (May/Jun - Aug) } \\
\text { (mm) }\end{array}$ \\
\hline 2013 & 24.5 & 34.3 & 308 & 255 & 820 & 111 \\
\hline 2014 & 23.2 & 32.8 & 321 & 157 & 776 & 67 \\
\hline 2015 & 24.9 & 34.6 & 288 & 95 & 940 & 165 \\
\hline
\end{tabular}

Table 2. Number of days with air temperature above 30,35 and $40^{\circ} \mathrm{C}$ during the three year of the trial, in Alentejo (South Portugal) along the growing cycle in 2013, 2014 and 2015.

\begin{tabular}{cccc}
\hline YEAR & N. days with $\mathbf{T}_{\text {air }}>\mathbf{>} \mathbf{3 5}^{\circ} \mathbf{C}$ & N. days with $\mathbf{T}_{\text {air }}>\mathbf{3 0 ^ { \circ } \mathbf { C }}$ & N. days $\mathbf{T}_{\text {air }}>\mathbf{4 0 ^ { \circ } \mathbf { C }}$ \\
\hline 2013 & $52(14,3 \%)$ & $111(30,4 \%)$ & $12(3,3 \%)$ \\
2014 & $30(8,2 \%)$ & $97(26,6 \%)$ & $2(0,6 \%)$ \\
2015 & $57(15,6 \%)$ & $115(31,5 \%)$ & $7(1,9 \%)$ \\
\hline
\end{tabular}

The ARA vines showed a tendency for lower leaf water potential especially in more stressfull conditions as compared to TOU (data not shown) suggesting that ARA vines may be losing more water along the season than TOU. This can be explained by differences in phenology of the two varieties (ARA has an earlier budbreak and shoot development) in combination with a larger total leaf area of ARA vines (e.g. 4.8-5.5 $\mathrm{m}^{2}$ (ARA) vs 4.4-5.1 $\mathrm{m}^{2}$ (TOU) in 2013 and 9.8-9.9 $\mathrm{m}^{2}$ (ARA) vs 8.3-8.4 $\mathrm{m}^{2}$ (TOU) in 2014) which might have contributed for larger transpiration water loss in ARA vines.

Tc correlated negatively with leaf water potential at pre-dawn (Fig. 1) and leaf gas exchange (not shown).Correlations showed the tendency for higher significance in the afternoon period and in the driest years (2013 and 2015). However, Tc was not able to discriminate the two varieties. The cluster zone of the canopy (canopy basal part) presented a temperature $\left(1-2{ }^{\circ} \mathrm{C}\right.$ higher on average) than the upper part of the canopy and $\mathrm{T}_{\mathrm{S}}$ was on average $10-$ $15^{\circ} \mathrm{C}$ higher than $T_{C}$ (Fig. 2). Variation in $T_{S}$ was coupled to daily variation of sun radiation, whereas Tc was influenced 
by water status and leaf gas exchange. Thermographic results were also validated by thermometry indicating the possibility of using thermography as robust tool to assess leaf temperature (Fig. 2).

Considering the influence of soil on canopy heat balance, soil management strategies together with irrigation strategies are crucial to influence soil/canopy heat exchange and hence, can be adjusted to reduce heat and drought stress risks.

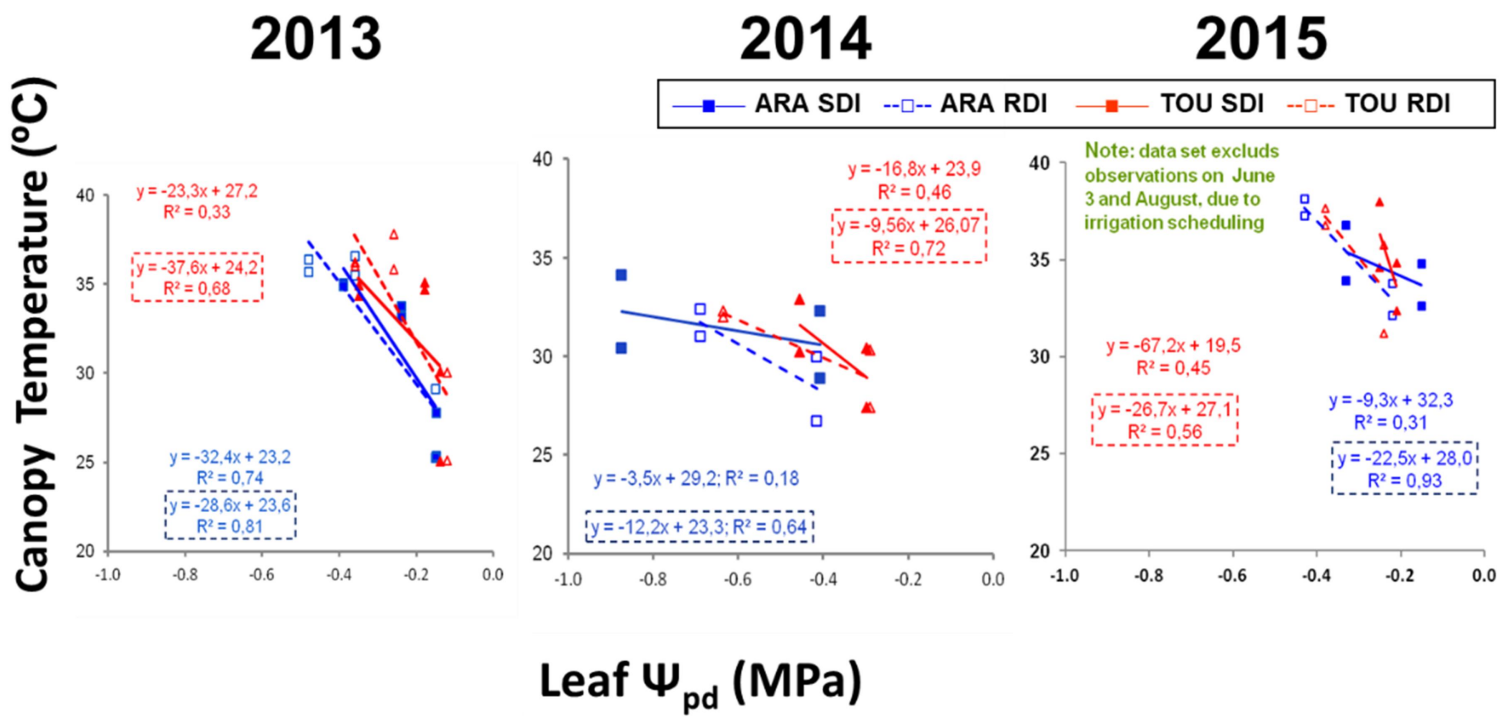

Fig.1. Relationships between canopy temperature $\left(T_{C}\right)$ and grapevine water status (leaf water potential at predawn $\left.\left(\Psi_{p d}\right)\right)$ measured for the two $\underline{V}$. vinifera varieties (Aragonez - ARA and Touriga Nacional - TOU) subjected to two deficit irrigation regimes SDI e RDI (see M\&M for details) measured in the three years of the trial (2013, 2014 and 2015). Measurements of $T_{C}$ were done between $14 \mathrm{~h}$ and $17 \mathrm{~h}$.
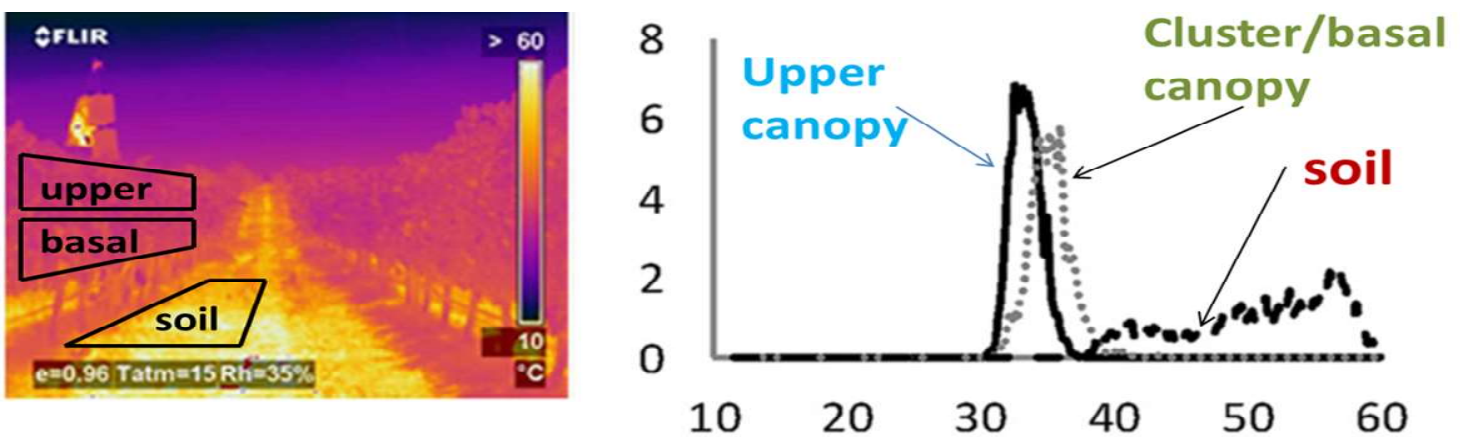

Fig. 2. Thermal image (left) and respective pixel frequency of the measured temperatures for $T_{C}$ (right) taken from IR images of two rows of ARA (17h, 19 July 2015) and showing the mean Tc for the upper part (upper) and basal part (cluster zone) of the canopy of $\mathrm{V}$. vinifera cV Aragonez (syn Tempranillo) and also soil temperature. ROls are selected on the sunlit area (facing West from 14:30 h to sunset). 


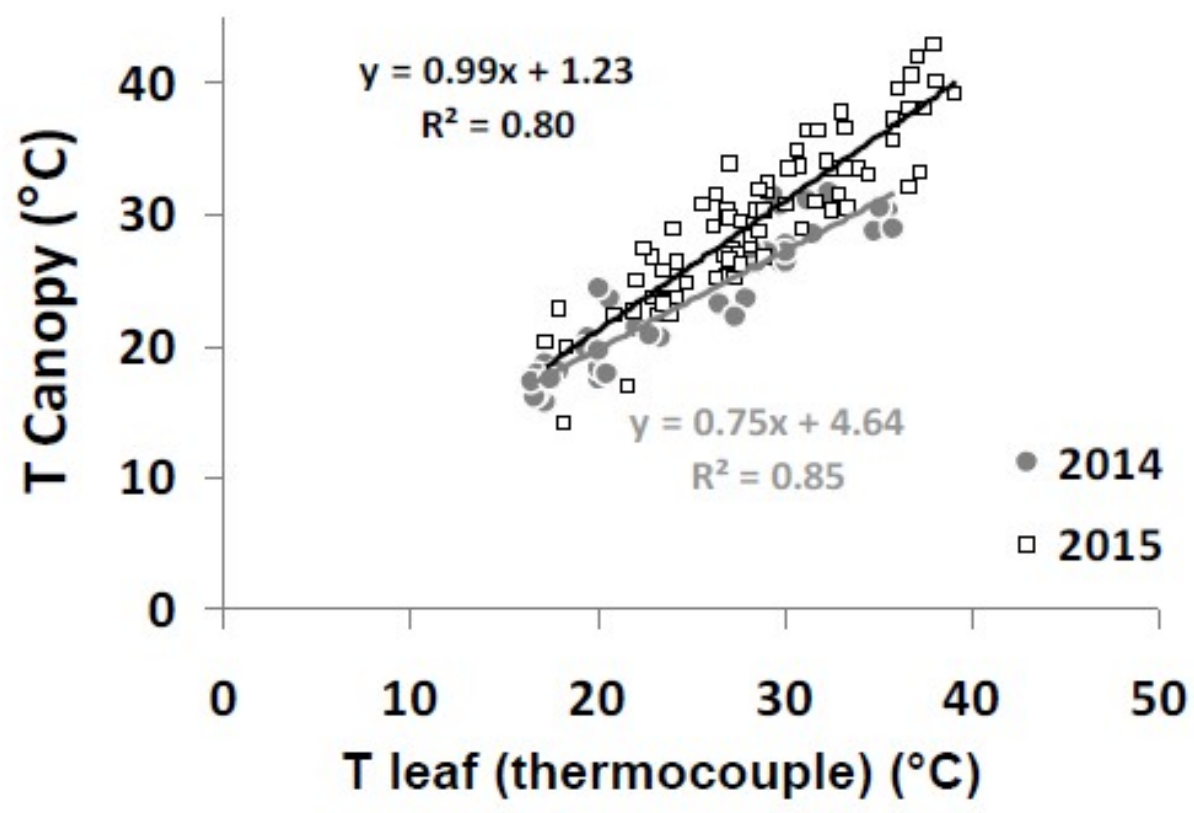

Fig. 3. Validation of thermography measurements of canopy temperature $\left(T_{C}\right)$ (Flir B20, 7-13 $\mu \mathrm{m}, 320 \times 240$ pixels; $\varepsilon=0.96$ ) by punctual measurements of leaf temperature $\left(T_{\text {leaf }}\right)$ done by thermometry (thermocouple), for $\underline{V}$. vinifera cv Aragonez (syn Tempranillo) in 2015.

\section{Conclusions}

Inter-annual climate variation induced a major variation in irrigation needs which represent a challenge to growers (Table 1). Differences between genotypes were only clear for $\Psi_{\mathrm{pd}}$. ARA had the lowest values of $\Psi_{\mathrm{pd}}$ suggesting the effect of its larger canopy area in the higher evaporative water loss. The overall Tc patterns were similar for both genotypes and the Tc is negatively correlated with leaf water potential, indicating that Tc is a simple but still robust thermal indicator of water status in grapevine [10]

Ts under sunlit conditions was about $10-15^{\circ} \mathrm{C}$ higher than Tc, suggesting an important influence of soil temperature and derived heat fluxes on canopy thermal condition especially under warm conditions. Further research on heat fluxes in vineyards is needed to optimize irrigation and mitigate the effects of supra-optimal temperatures on grapevine physiology. This suggests that thermal variables ( $T_{\text {air, }}, T_{C}, T_{\text {berry }}$ and $T_{S}$ ) could be useful to feed models for Decision Support Systems because such thermal variables have an impact on plant/berry ecophysiology, on evapotranspiration, soil activity as well as on heat exchange in vineyards (Fig. 4).

Finally, we may also envisage that the use of aerial thermal imaging in viticulture (e.g. by UAVs, satellite) $[11,12]$ will increase the relevance of thermal variables in order to estimate plants/crop transpiration and soil evaporation and to support irrigation needs and scheduling to minimize risks or losses to drought and/or heat stress. This information can be even more relevant for heat wave conditions. 


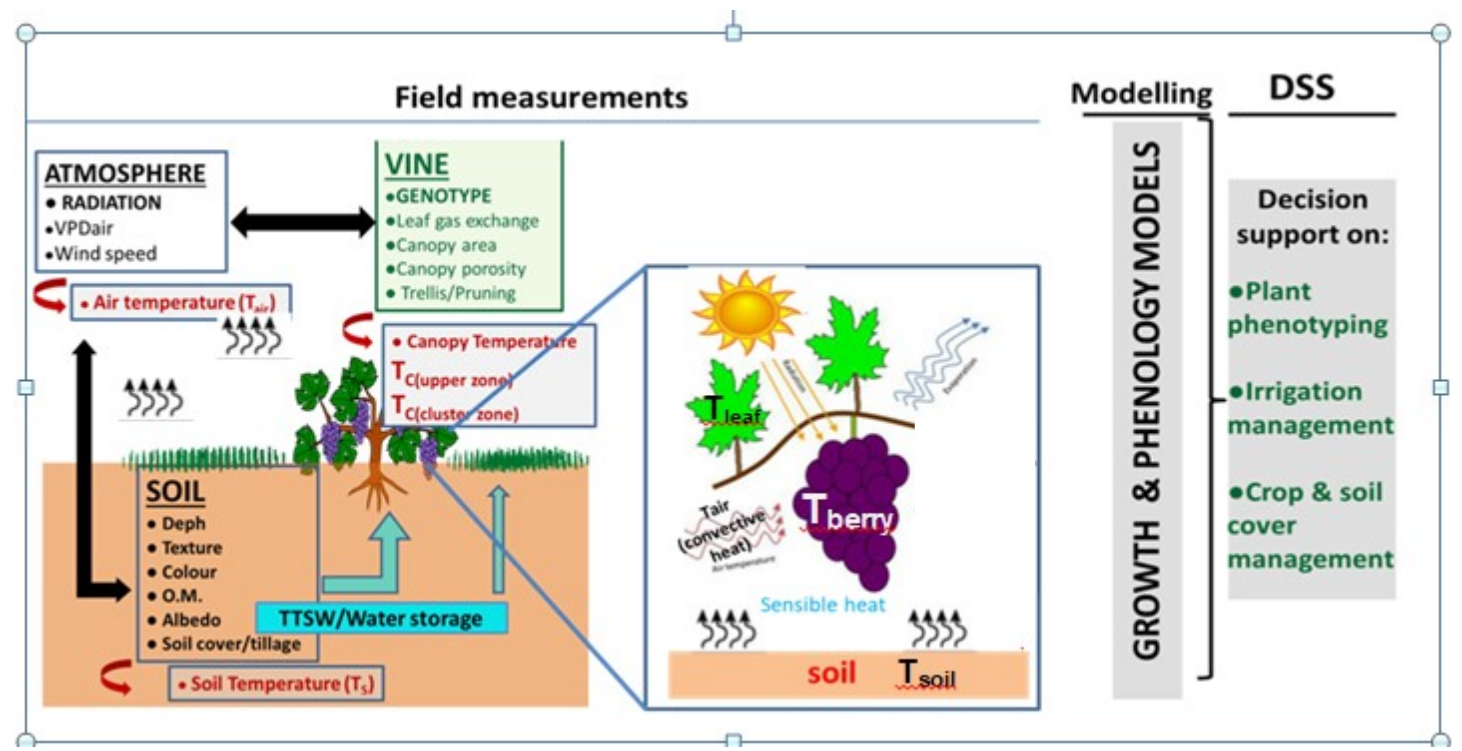

Fig.4. Diagram illustrating the potential interactions between soil, canopy and berries in terms of heat exchange and temperature regulation and the use of Tair, $T_{S}, T c$, and $T_{\text {berry }}$ as parameters to feed models to support decision on plant phenotyping, and vineyard management (irrigation, canopy and soil). TTSW - total transpirable soil water

\section{Acknowledgements}

This research received funding from European Community's Seventh Framework Programme (FP7/2007-2013) under the grant agreement $n^{\circ}$ FP7-311775, Project INNOVINE. Participation in the QIRT congress received the support of Fundação para a Ciência e Tecnologia via the projects PTDC/ASP-PLA/28726/2017 "Fostering High Throughput Plant Phenotyping by an Interdisciplinary Approach" and UID/Multi/04046/2019 (BioISI).

\section{REFERENCES}

[1] Teskey RO, Wertin TM, Bauweraerts I., Ameye M., McGuireM.A. Steppe K. 2014. Responses of tree species to heat waves and extreme heat events. Plant Cell Environment. DOI: 10.1111/pce.12417.

[2] Rogiers SY, Clarke SJ 2014. Nocturnal and daytime stomatal conductance respond to root-zone temperature in 'Shiraz' grapevines. Annals of Botany doi:10.1093/aob/mcs298

[3] Fraga H, Molitor D, Leolini L,, Santos J (2020). What Is the Impact of Heatwaves on European Viticulture? A Modelling Assessment". Applied Sciences 10 (9): 3030.

[4] Sauer, T.J., R. Horton. 2005. Soil heat flux. In: J.L. Hatfield and J.M. Baker (Editors), Micrometeorology in agricultural systems. ASA Monograph 47: 131-154. American Society of Agronomy, Madison, Wisconsin. doi: 10.2134/agronmonogr47.c

[5] Costa, JM., Egipto, R., Silvestre, J., Lopes, CM., Chaves, MM. 2018. Water and heat fluxes in Mediterranean vineyards: indicators and relevance for management. In: Water Scarcity and Sustainable Agriculture in Semiarid Environment. IF Garcia-Tejero, V.H Duran Zuazo (Eds), Elsevier, pp. 219-245. ISBN: 9780128131640, https://doi.org/10.1016/B978-0-12-813164-0.00010-7

[6] Sauer, T.J. and R. Horton. 2005. Soil heat flux. In: J.L. Hatfield and J.M. Baker (Editors), Micrometeorology in agricultural systems. ASA Monograph 47: 131-154. American Society of Agronomy, Madison, Wisconsin. doi: 10.2134/agronmonogr47.c7.

[7] Schultz, H.R. The soil as an important part in the interaction with plant functioning and fruit quality under climate change-An integrated view on a moving target. In Proceedings of the OENOVITI, International Symposium, Athens, Greece, 12-14 May 2019; p. 4. 
[8] Chaves M.M., Zarrouk O., Francisco R., Costa J.M., Santos T., Regalado A.P., Rodrigues M.L., Lopes C.M., 2010. Grapevine under deficit irrigation: hints from physiological and molecular data. Ann Bot., 105: 661-676;

[9] Costa J.M., Vaz M., Escalona J., Egipto R., Lopes C., Medrano H., Chaves M.M., 2016. Modern viticulture in southern Europe: Vulnerabilities and strategies for adaptation to water scarcity. Agric Water Manag., 164: 5-18.

[10] García-Tejero IF, Costa JM, Egipto R, Durán-Zuazo VH, Lima RSN, Lopes CM, Chaves MM (2016). Thermal data to monitor crop-water status in irrigated Mediterranean viticulture. Agricultural Water Management, 176: $80-90$

[11] Matese, A.; Toscano, P.; Di Gennaro, S.F.; Genesio, L.; Vaccari, F.P.; Primicerio, J.; Belli, C.; Zaldei, A.; Bianconi, R.; Gioli, B. Intercomparison of UAV, Aircraft and Satellite Remote Sensing Platforms for Precision Viticulture. Remote Sensing 2015, 7, 2971-2990.

[12] Gago, J., Estrany, J., Estes, L., Fernie, A. R., Alorda, B., Brotman, Y.,Flexas, J., Escalona, J. M., \& Medrano, H. (2020). Nano and micro unmanned aerial vehicles (UAVs): A new grand challenge for precision

agriculture? Current Protocols in Plant Biology, 5, e20103.doi: 10.1002/cppb.20 